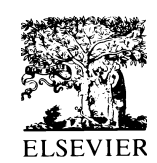

\title{
A Study on Ternary Ti-rich TiNiZr Shape Memory Alloys
}

\author{
S. F. Hsieh and S. K. Wu \\ Institute of Materials Science and Engineering, National Taiwan University, Taipei, Taiwan 106, \\ Republic of China
}

\begin{abstract}
The martensitic transformation in $\mathrm{Ti}_{50.5-\mathrm{X}} \mathrm{Ni}_{49.5} \mathrm{Zr}_{X}$ and $\mathrm{Ti}_{51.5-\mathrm{X}} \mathrm{Ni}_{48.5} \mathrm{Zr}_{X}$ alloys $(X=0-25$ at.\%) was studied by using thermomechanical treatments. These alloys have a B2 $\leftrightarrow$ B19' transformation sequence, and their transformation peak temperature $M^{*}$ can be raised to $50-450^{\circ} \mathrm{C}$ by different additions of Zr. Although a great many second-phase particles exist around $(\mathrm{Ti}, \mathrm{Zr}) \mathrm{Ni}$ grain boundaries, these alloys still exhibit $\geq 80 \%$ shape-memory recovery. Thermal cycling can depress the $M^{*}$ temperature more significantly in the $\mathrm{Ti}_{41.5} \mathrm{Ni}_{48.5} \mathrm{Zr}_{10}$ alloy than in the $\mathrm{Ti}_{40.5} \mathrm{Ni}_{49.5} \mathrm{Zr}_{10}$ alloy in the first ten cycles, owing to the former's having greater hardness and more second-phase particles. Martensite stabilization can be induced by cold rolling at room temperature for Ti-rich ternary TiNiZr alloys. The strengthening effects of cold rolling and thermal cycling on $\mathrm{M}_{\mathrm{s}}$ temperatures of these alloys were found to follow the expression $\mathrm{M}_{\mathrm{s}}=T_{0}-K \Delta \sigma_{\mathrm{y}}$, in which $K$ values are related to the as-annealed hardness of these alloys. For the study of $400^{\circ} \mathrm{C}$ aging effects, the martensite stabilization appearing in the $\mathrm{Ti}_{26.5} \mathrm{Ni}_{48.5} \mathrm{Zr}_{15}$ alloy may be due to the pinning effect on the interfaces of martensite plates by the point defects. (C) Elsevier Science Inc., 1998
\end{abstract}

\section{INTRODUCTION}

Among the reported shape-memory alloys (SMAs), TiNi alloys are the most attractive ones because of their excellent shape-memory effect and pesudoelasticity. However, they are limited to being used at a temperature lower than $150^{\circ} \mathrm{C}$ because their martensitic transformation starting temperature, $\mathrm{M}_{\mathrm{s}}$, is usually lower than $100^{\circ} \mathrm{C}$. Hightemperature SMAs with an $\mathrm{M}_{\mathrm{s}}$ temperature higher than $100^{\circ} \mathrm{C}$ have been exhaustively researched owing to their potential applications. Ternary TiNiX high-temperature SMAs-with $\mathrm{X}$ being precious metals $\mathrm{Pd}$, $\mathrm{Pt}$, and $\mathrm{Au}-$ also have been developed [14]. However, the high cost of precious metals limits the practical application of these alloys. For this reason, other TiNiX hightemperature SMAs need to be investigated. Among them, TiNiZr SMAs are the most prospective ones.
Meisner and Sivokha [5] reported that $(\mathrm{Ti}, \mathrm{Zr})_{2} \mathrm{Ni}_{7},(\mathrm{Ti}, \mathrm{Zr})_{7} \mathrm{Ni}_{10}$ and $\mathrm{NiZr}$ phases can be observed in Ni-rich $\mathrm{Ti}_{50-x} \mathrm{Ni}_{50} \mathrm{Zr}_{X}$ alloys with $\mathrm{Zr}$ content in the range of 30 50 at.\% at room temperature. Three phases, $(\mathrm{Ti}, \mathrm{Zr}) \mathrm{Ni},(\mathrm{Ti}, \mathrm{Zr})_{2} \mathrm{Ni}$, and $\lambda_{1}$, are observed at room temperature in Ti-rich $\mathrm{Ti}_{53-\mathrm{X}} \mathrm{Ni}_{47} \mathrm{Zr}_{\mathrm{X}}$ alloys with the $\mathrm{Zr}$ content in the range of 520at.\% [6]. Here, the $\lambda_{1}$ phase is a TiNiZr ternary solid solution and the $(\mathrm{Ti}, \mathrm{Zr}) \mathrm{Ni}$ phase can exhibit B2 $\leftrightarrow$ B19' martensitic transformation with an $M_{\mathrm{s}}$ temperature in the range of $60-260^{\circ} \mathrm{C}$ [6]. Meanwhile, Mulder et al. [7] reported that the decrease in transformation temperatures in the thermally cycled $\mathrm{Ti}_{31.5} \mathrm{Ni}_{48.5} \mathrm{Zr}_{20}$ alloy is affected by the $(\mathrm{Ti}, \mathrm{Zr})_{2} \mathrm{Ni}$ precipitates.

It has been confirmed that the properties of Ti-rich TiNi binary SMAs can be affected by various thermomechanical treatments, such as thermal cycling, aging, and cold rolling [8]. However, few reports have been 
made on Ti-rich TiNiZr ternary alloys [9] whose transformation behaviors and shapememory characteristics are affected by different thermomechanical treatments. The aim of the present work is to systematically investigate the general characteristics of Tirich TiNiZr SMAs. The effects of aging, cold rolling, and thermal cycling on these also are discussed.

\section{EXPERIMENTAL PROCEDURE}

The conventional tungsten arc melting technique was employed to prepare $\mathrm{Ti}_{50.5-}$ ${ }_{X} \mathrm{Ni}_{49.5} \mathrm{Zr}_{X}$ (A alloys) and $\mathrm{Ti}_{51.5-X} \mathrm{Ni}_{48.5} \mathrm{Zr}_{X}$ (B alloys) alloys with $X=0-25$ at.\%. Titanium (purity, 99.7\%wt.\%), nickel (purity, 99.9wt.\%), and aluminum (purity, 99.9wt.\%), totaling about $120 \mathrm{~g}$, were melted and remelted at least six times in an argon atmosphere. A pure titanium button was used as a getter during the arc melting. Weight loss during melting was negligibly small. The as-melted ingots were homogenized at $950^{\circ} \mathrm{C} \times 72 \mathrm{~h}$ and then quenched in water. The ingots were cut into several plates with a low-speed diamond saw and then annealed at $900^{\circ} \mathrm{C} \times 2 \mathrm{~h}$ and quenched in water. After the annealing treatment, three experimental procedures were conducted. First, several plates were vacuum sealed in quartz tubes and aged at $400^{\circ} \mathrm{C}$ for $1 \mathrm{~h}$ to $100 \mathrm{~h}$ and then quenched in water. Second, several more plates were cold rolled at room temperature to $5 \%, 10 \%, 15 \%$, and $25 \%$ reductions in thickness. Third, other plates were subjected to thermal cycling $N$ times from $0^{\circ} \mathrm{C}$ to $300^{\circ} \mathrm{C}$ with $N=1-100 \mathrm{cy}-$ cles. Specimens for a DSC measurement, hardness test, shape-recovery test, internal friction test, and microstructure observation were carefully cut from plates treated in accord with the aforedescribed procedures. DSC measurements were made with a Dupont 2000 thermal analyzer equipped with a quantitative scanning system 910 DSC cell for controlled heating and cooling runs on samples encapsulated in an aluminum pan. The running temperature range was from $0^{\circ} \mathrm{C}$ to $400^{\circ} \mathrm{C}$ with a heating and cooling rate of $10 \mathrm{C}^{\circ} /$ minute. An internal friction test was carried out with a SINKURIKO $1500 \mathrm{M} / \mathrm{L}$ series inverted torsion pendulum in the temperature range from $-150^{\circ} \mathrm{C}$ to $250^{\circ} \mathrm{C}$. The temperature rate was precisely controlled at $2 \mathrm{C}^{\circ} /$ minute, and the test frequency was approximately $1 \mathrm{~Hz}$. Specimens for the hardness test were first mechanically polished and then subjected to measurement in a Vickers microhardness tester with a $500 \mathrm{~g}$ load at room temperature. For each specimen, the average hardness value was taken from at least five test readings. The microstructural observations were made by transmission electron microscopy with a JOEL-100CXII microscope equipped with a conventional double-tilting stage. The shape-recovery measurement was performed as described by Lin and $\mathrm{Wu}$ [10]. A quantitative analysis of each alloy's chemical composition was performed by using a JOEL JXA-8600SX electron probe microanalyzer (EPMA) equipped with a WDX analysis system.

\section{EXPERIMENTAL RESULTS AND DISCUSSION}

\author{
TRANSFORMATION BEHAVIOR IN

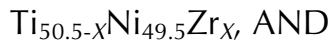 \\ $\mathrm{Ti}_{51.5-X} \mathrm{Ni}_{48.5} \mathrm{Zr}_{X}$ ALLOYS
}

Figure 1 shows the experimental results of DSC measurements for the annealed $\mathrm{Ti}_{50.5-}$ ${ }_{X} \mathrm{Ni}_{49.5} \mathrm{Zr}_{X}$ (A alloys) and $\mathrm{Ti}_{51.5-X} \mathrm{Ni}_{48.5} \mathrm{Zr}_{X}$ (B alloys) alloys with $X=0-20 a t . \%$ or $0-$ 25at.\% in both forward and reverse transformations, respectively. The peaks $M^{*}$ and $A^{*}$ (including $M_{s}, M_{f}, A_{s}$, and $A_{f}$ points) appearing in Fig. 1 are associated with the martensite transformation of $\mathrm{B} 2 \leftrightarrow \mathrm{M}$. Here $\mathrm{M}_{\mathrm{s}}$ and $\mathrm{M}_{\mathrm{f}}$ indicate the starting and finishing temperatures, respectively, of the martensitic transformation; $\mathrm{A}_{\mathrm{s}}$ and $\mathrm{A}_{\mathrm{f}}$ refer to the starting and finishing temperatures, respectively, of the reverse martensitic transformation. The transformation peak temperatures versus $\mathrm{Zr}$ content shown in Fig. 1 are plotted in Fig. 2. From Fig. 2, it is clear that the transformation peak temperatures 

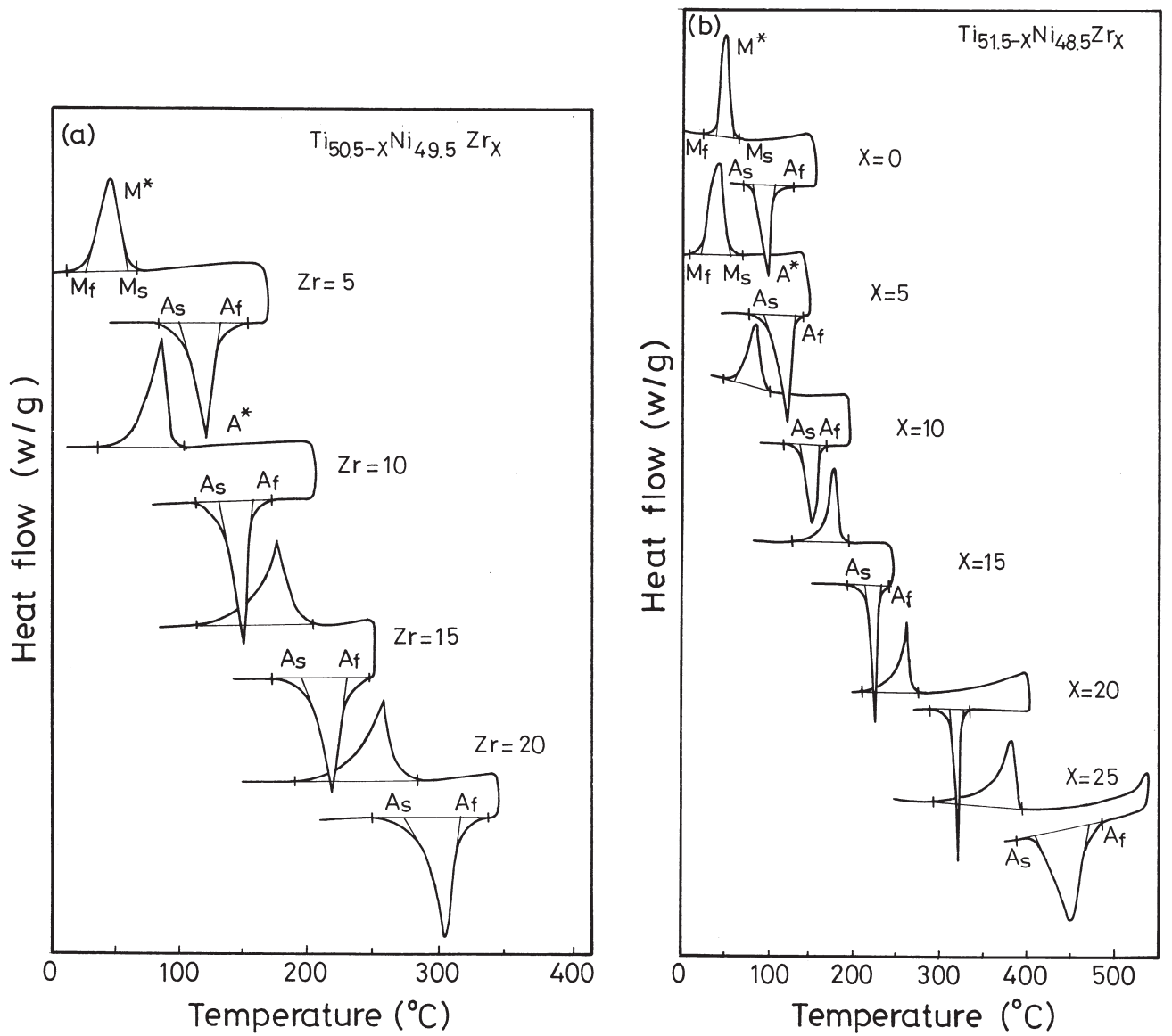

FIG. 1. DSC curves of as-annelaed (a) $\mathrm{Ti}_{50.5-X} \mathrm{Ni}_{49.5} \mathrm{Zr}_{X}\left(X=0-20\right.$ at.\%) and (b) $\mathrm{Ti}_{51.5-X} \mathrm{Ni}_{48.5} \mathrm{Zr}_{X}$ alloys $(X=0-25 a t . \%)$. $\mathrm{M}^{*}$ and $\mathrm{A}^{*}$ are peak temperatures of forward and reverse martensitic transformation, respectively.

increase from $50^{\circ} \mathrm{C}$ to $450^{\circ} \mathrm{C}$ with a relatively increasing $\mathrm{Zr}$ content. Therefore, on the basis of the results of Fig. 2, a TiNiZr SMA alloy with a desired transformation temperature can be obtained by carefully controlling its corresponding $\mathrm{Zr}$ content. For the same $\mathrm{Zr}$ content, the $\mathrm{A}^{*}$ and $\mathrm{M}^{*}$ temperatures of $\mathrm{B}$ alloys are higher than those of A alloys. This characteristic is similar to that of the Ti-rich TiNi binary alloys. The $\mathrm{A}_{\mathrm{s}}$ temperature of TiNi binary alloys is reported to increase linearly as the $\mathrm{Ti}$ content increases to as much as $50.5 \mathrm{at} . \%$ and then levels off at approximately $113^{\circ} \mathrm{C}$ [11]. Thus, we propose that the $\mathrm{A}_{\mathrm{s}}$ temperature of Ti-rich TiNiZr alloys also can increase as the $(\mathrm{Ti}+\mathrm{Zr})$ content increases to $51.5 \mathrm{at} . \%$.

Figure 3(a) shows the TEM bright field image of martensite in annealed $\mathrm{Ti}_{30.5} \mathrm{Ni}_{49.5} \mathrm{Zr}_{20}$

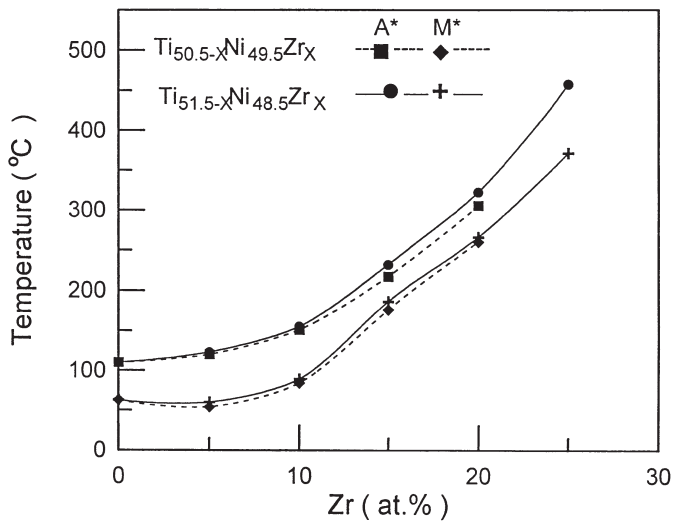

FIG. 2. Transformation temperatures of $A^{*}$ and $M^{*}$ versus $\mathrm{Zr}$ content for $\mathrm{Ti}_{50.5-\mathrm{X}} \mathrm{Ni}_{49.5} \mathrm{Zr}_{X}$ and $\mathrm{Ti}_{51.5-}$ ${ }_{X} \mathrm{Ni}_{48.5} \mathrm{Zr}_{X}$ alloys. 

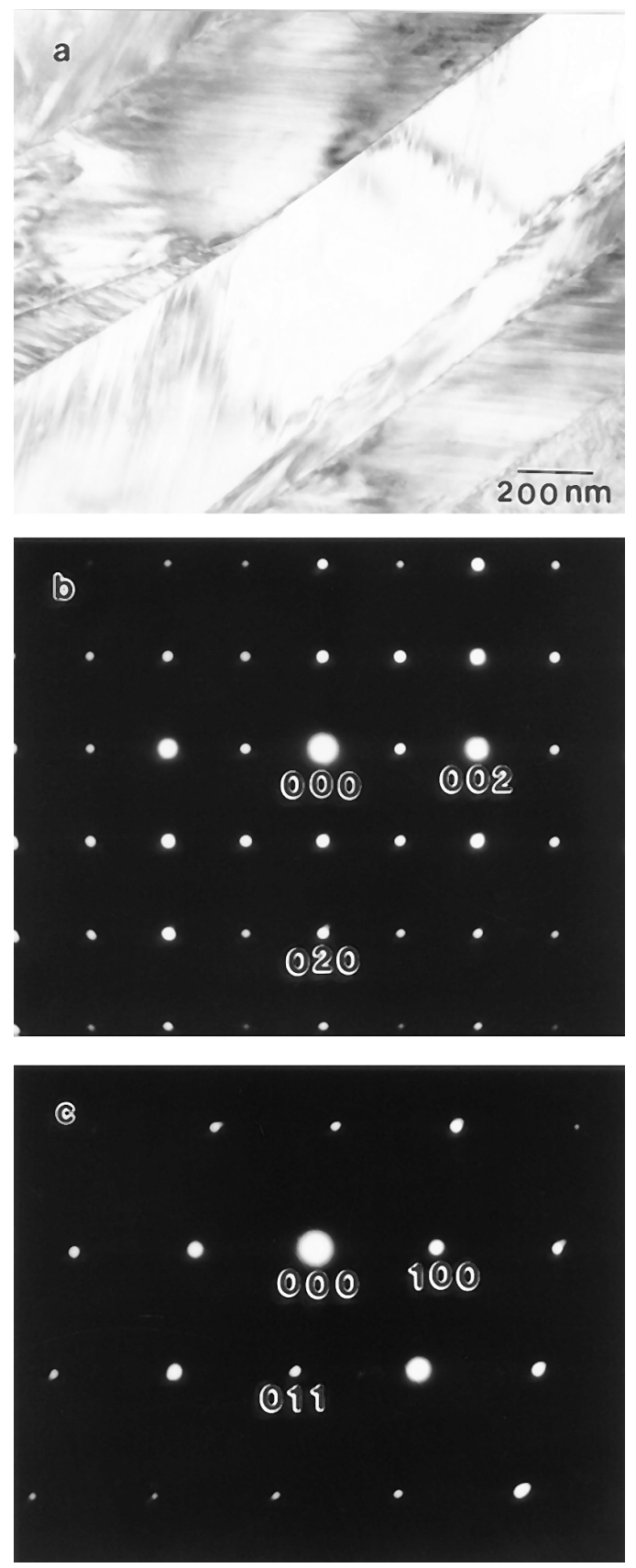

FIG. 3. Transmission electron micrographic brightfield image of as-annelaed $\mathrm{Ti}_{30.5} \mathrm{Ni}_{49.5} \mathrm{Zr}_{20}$ alloy. (b) SADP of (a) with [100] $]_{M}$ zone axis. (c) SADP of (a) with $[01 \overline{1}]_{\mathrm{M}}$ zone axis.

alloy. Figure 3(b, c) shows the selected area diffraction patterns (SADPs) of this alloy, in which the foil is parallel to $[100]_{M}$ and $[011]_{\mathrm{M}}$ directions, respectively. Han et al.
[12] found that the lattice parameter of martensite in the $\mathrm{Ti}_{36.5} \mathrm{Ni}_{48.5} \mathrm{Hf}_{15}$ alloy is a monoclinic B19' structure with $a=0.293 \mathrm{~nm}, b=$ $0.411 \mathrm{~nm}, c=0.473 \mathrm{~nm}$, and $\beta=100.4^{\circ}$. The SADPs of Fig. 3(b, c) coincide with those of Han's results; therefore, the structure of martensite in the $\mathrm{Ti}_{30.5} \mathrm{Ni}_{49.5} \mathrm{Zr}_{20}$ alloy is suggested to be monoclinic B19' structure.

Figure 4 shows plots of frequency, $f$ (shear modulus), and internal friction, $Q^{-1}$, versus the temperature of the annealed $\mathrm{Ti}_{40.5} \mathrm{Ni}_{49.5} \mathrm{Zr}_{10}$ alloy. In Fig. $4(\mathrm{~b})$, there is one peak, $\mathrm{P}_{\mathrm{C}}$ at $84^{\circ} \mathrm{C}$ on cooling and one peak, $\mathrm{P}_{\mathrm{H}}$, at $151^{\circ} \mathrm{C}$ on heating; both peaks correspond to the minima of frequency $f$, as shown in Fig. 4(a). These two peaks are associated with the martensitic transformation [13]. The peak $P_{R}$ appearing at $-38^{\circ} \mathrm{C}$, not corresponding to the minimum of frequency $f$, is proposed to be a relaxation peak $[14,15]$. In the TiNi binary SMA, this kind of relaxation peak is suggested to be associated with the interaction of dislocations and point defects [15] and is independent of the martensite and premartensite transformations [13]. The temperature difference $\Delta T$ between $\mathrm{P}_{\mathrm{H}}$ and $\mathrm{P}_{\mathrm{C}}$ is approximately $67 \mathrm{C}^{\circ}$ for the $\mathrm{Ti}_{40.5} \mathrm{Ni}_{49.5} \mathrm{Zr}_{10}$ alloy, which is larger than that of the $\mathrm{Ti}_{51} \mathrm{Ni}_{49}$ alloy $\left(\Delta T=41 C^{\circ}\right)$ [8]. This feature indicates that the $\mathrm{Zr}$ atoms in solid solution in Ti-rich TiNi alloys will result in a different chemical free energy between binary TiNi and ternary TiNiZr SMAs. From Figs. 1, 3, and 4 , the transformation sequence of martensite in alloys $\mathrm{A}$ and $\mathrm{B}$ is found to be a $\mathrm{B} 2 \leftrightarrow \mathrm{B} 19^{\prime}$ sequence.

Figure 5 shows EPMA backscattering electron images (BEIs) of $900^{\circ} \mathrm{C}$ annealed A alloys with $X=5,10,15$, and 20at.\%, respectively. A great many second-phase particles are found around the grain boundaries of the matrix. The chemical compositions of the matrix and secondphase particles found by EPMA analysis are given in Table 1 . The ratio $(\mathrm{Ti}+\mathrm{Zr}) / \mathrm{Ni}$ of the matrix and that of the second-phase particles also are shown in Table 1. On the basis of a previous paper [6], the results in Table 1 indicate that the matrix in Fig. 5 is the $(\mathrm{Ti}, \mathrm{Zr}) \mathrm{Ni}$ phase; the black particles are 

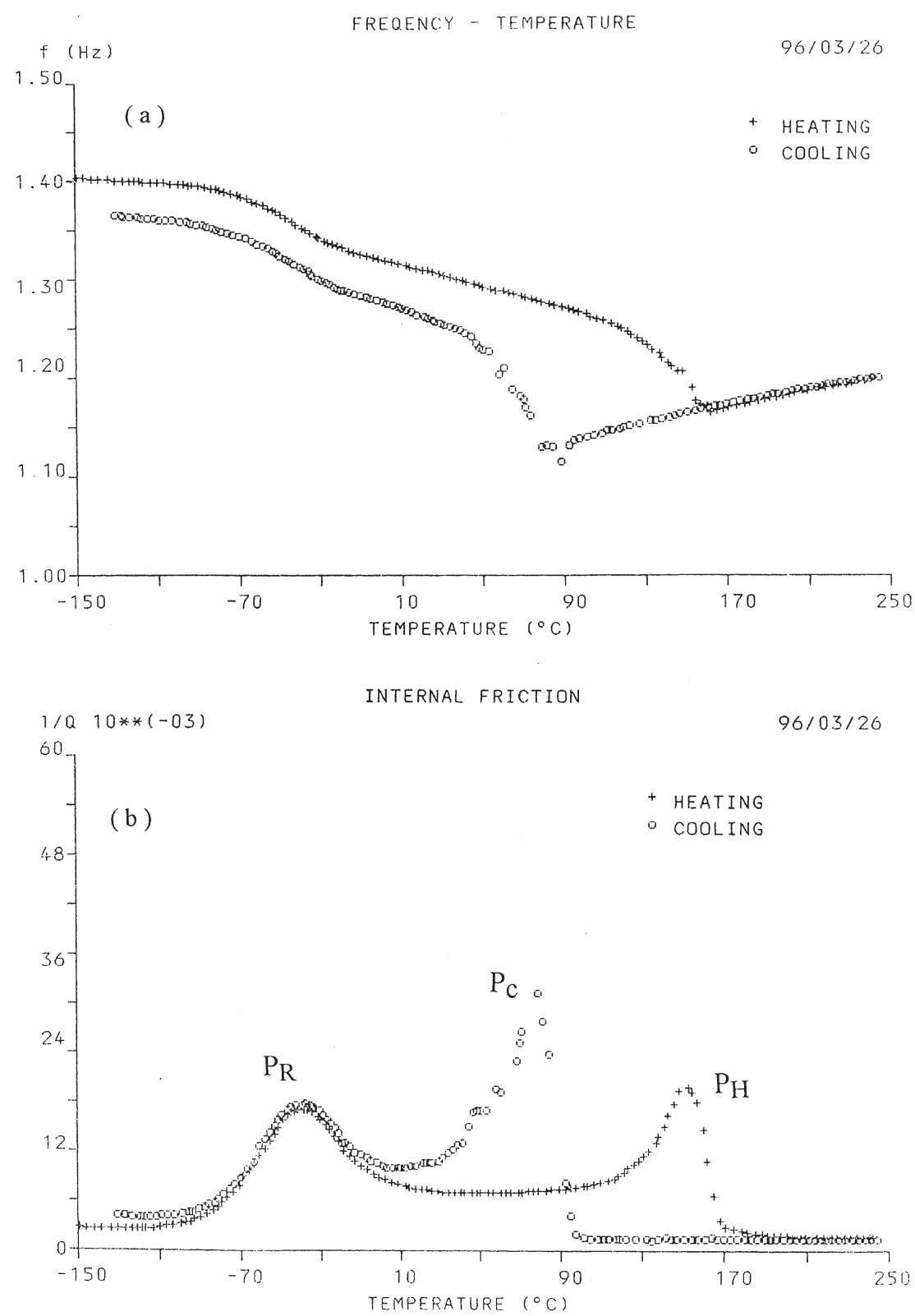

FIG. 4. (a) Frequency, $f$, and (b) internal friction, $Q^{-1}$, versus temperature for the $T_{40.5} \mathrm{Ni}_{49.5} \mathrm{Zr}_{10}$ alloy. Peaks $\mathrm{P}_{\mathrm{C}}$ and $\mathrm{P}_{\mathrm{H}}$ are associated with the martensitic transformation and peak $\mathrm{P}_{\mathrm{R}}$ is a relaxation one.

the $(\mathrm{Ti}, \mathrm{Zr})_{2} \mathrm{Ni}$ phase for alloys with $X \leq$ 10 at. $\%$ and are the $\lambda_{1}$ phase for alloys with $X \geq 15$ at.\%. The microstructures of B alloys are similar to those of A alloys and are thus omitted here. However, the volume fractions of second-phase particles are quite different for these two alloys, approximately $10 \%$ for the former and $4 \%$ for the latter.
Figure 6 shows the shape-memory characteristics of alloys A and B, respectively. Despite the existence of many more second-phase particles, B alloys still exhibit rather good shape recovery, which can reach about $80 \%$. It is rather uncommon that the shape recovery of Ti-rich $\mathrm{TiNiZr}$ ternary SMAs is not so much at the $A_{f}$ temperature. For example, from Fig. 6, the 

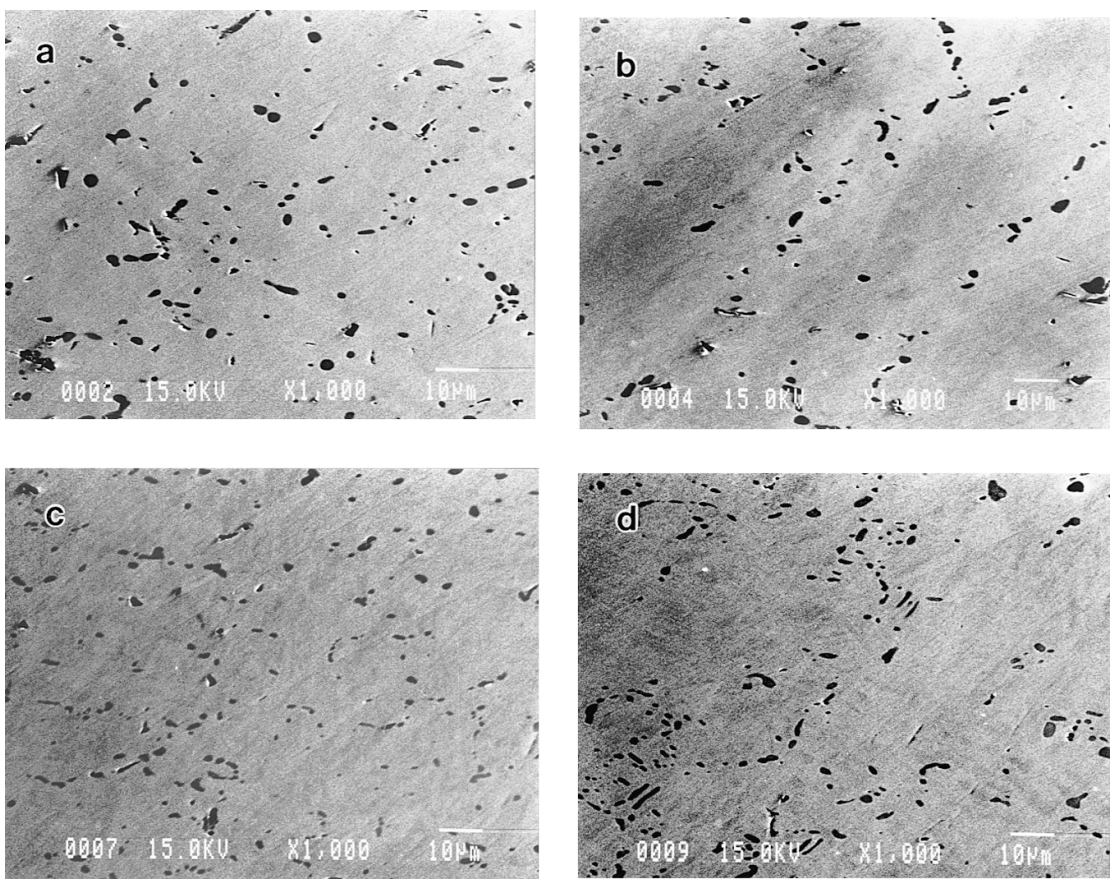

FIG. 5. BEIs of annealed $\mathrm{Ti}_{50.5-X} \mathrm{Ni}_{49.5} \mathrm{Zr}_{X}$ alloys with (a) $X=5$, (b) $X=10$, (c) $X=15$, and (d) $X=20$ at.\%.

shape recovery of alloys A or B for $X=10$ reaches about $60 \%$ at $A_{f}$ temperature, but gradually increases with increasing temperature at $T_{\text {heating }} \geqq \mathrm{A}_{\mathrm{f}}$. Lin et al. [8] reported that the shape recovery of the equiatomic or Ni-rich $\mathrm{TiNi}$ alloys can reach about $90 \%$ at $T_{\text {heating }}=\mathrm{A}_{\mathrm{f}}$ and undergo only minor recovery during the subsequent heating. We believe that the aforementioned difference is closely related to the existence of second-phase particles; this phenomenon is also observed in binary Tirich $\mathrm{Ti}_{51} \mathrm{Ni}_{49}$ alloy [8]. These particles do not transform martensitically when the temperature changes. They are characterized by high brittleness and limited plasticity. Therefore, the shape recovery of A alloys is slightly more than that of B alloys, owing to A alloys having few particles, as shown in Fig. 6.

\section{THERMAL CYCLING EFFECTS ON Ti-RICH TiNiZr ALLOYS}

Figure 7 shows peak temperatures $\mathrm{M}^{*}$ and $\mathrm{A}^{*}$ and hardness, $\mathrm{HV}$ versus thermal cycle, $N$, for annealed $\mathrm{Ti}_{40.5} \mathrm{Ni}_{49.5} \mathrm{Zr}_{10}$ and $\mathrm{Ti}_{41.5} \mathrm{Ni}_{48.5} \mathrm{Zr}_{10}$ alloys, respectively. In Fig. 7 , the $\mathrm{M}^{*}$ and $\mathrm{A}^{*}$ temperatures decrease, but the hardness, $\mathrm{HV}$, increases with increasing thermal cycling $N$. It has been proposed that this fea-

Table 1 Compositional Analyses by EPMA for $\mathrm{Ti}_{50.5-\mathrm{X}} \mathrm{Ni}_{49.5} \mathrm{Zr}_{X}$ Alloys Annealed at $950^{\circ} \mathrm{C} \times 24 \mathrm{~h}$

\begin{tabular}{|c|c|c|c|c|c|}
\hline \multirow{2}{*}{\multicolumn{2}{|c|}{$\mathrm{Ti}_{50.5-\mathrm{X}} \mathrm{Ni} i_{49.5} \mathrm{Zr_{X }}$ alloys }} & \multicolumn{3}{|c|}{ Composition (at.\%) } & \multirow{2}{*}{ 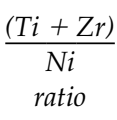 } \\
\hline & & $\mathrm{Ti}$ & $\mathrm{Ni}$ & $\mathrm{Zr}$ & \\
\hline \multirow[t]{3}{*}{$X=5$} & Matrix & 46.14 & 48.79 & 5.07 & 1.05 \\
\hline & Second & & & & \\
\hline & phase & 59.36 & 33.70 & 6.94 & 1.97 \\
\hline \multirow[t]{3}{*}{$X=10$} & Matrix & 40.81 & 49.01 & 10.18 & 1.04 \\
\hline & Second & & & & \\
\hline & phase & 55.52 & 33.19 & 10.29 & 1.98 \\
\hline \multirow[t]{3}{*}{$X=15$} & Matrix & 36.45 & 49.18 & 14.37 & 1.03 \\
\hline & Second & & & & \\
\hline & phase & 46.80 & 37.55 & 15.65 & 1.66 \\
\hline \multirow[t]{3}{*}{$X=20$} & Matrix & 31.50 & 48.88 & 19.62 & 1.04 \\
\hline & Second & & & & \\
\hline & phase & 40.43 & 37.96 & 21.61 & 1.63 \\
\hline
\end{tabular}



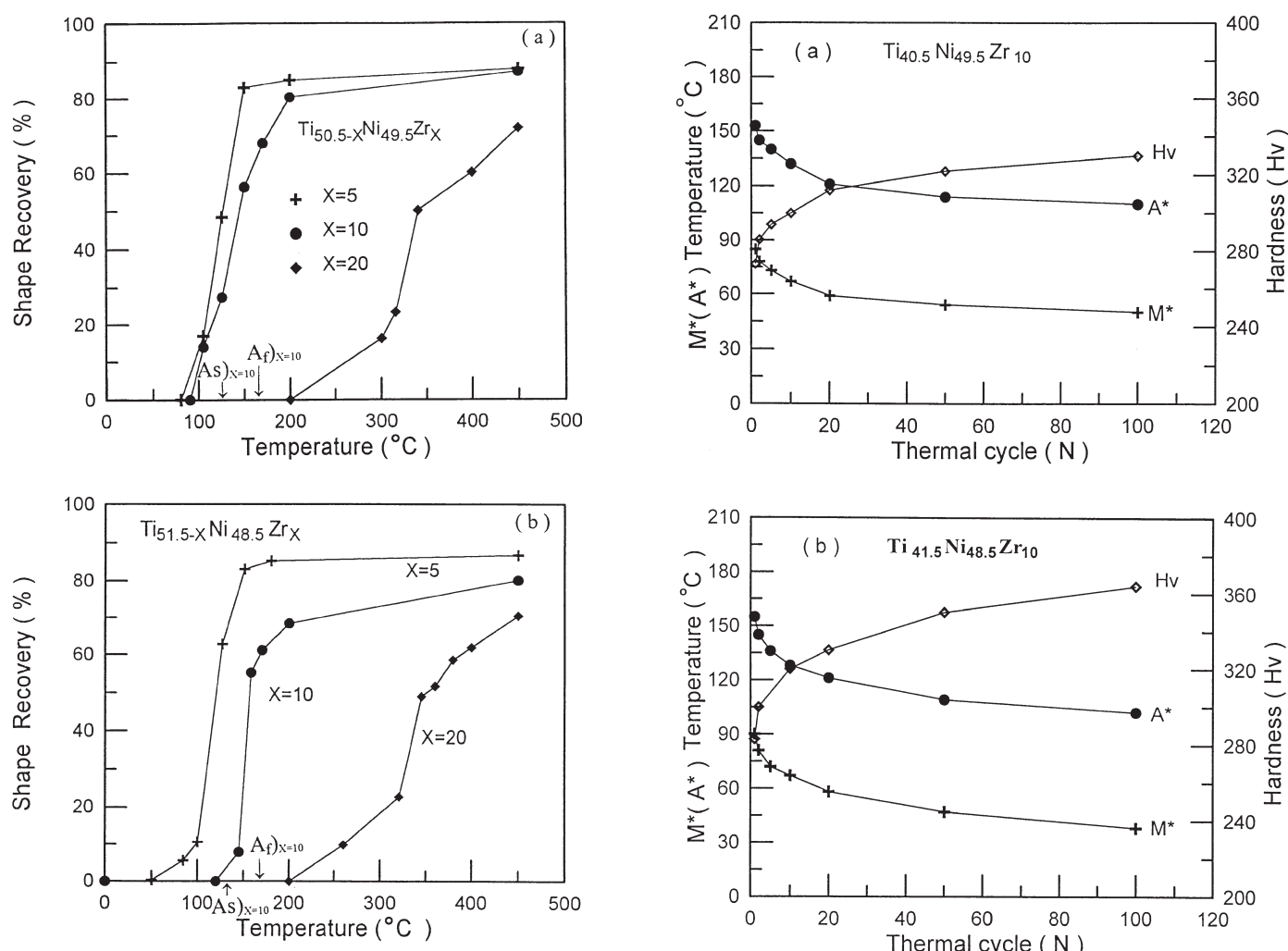

FIG. 6. Shape recovery versus heating temperature for (a) $\mathrm{Ti}_{50.5-\mathrm{X}} \mathrm{Ni}_{49.5} \mathrm{Zr}_{X}$ alloys and (b) $\mathrm{Ti}_{51.5-\mathrm{X}} \mathrm{Ni}_{48.5} \mathrm{Zr}_{X}$ alloys.

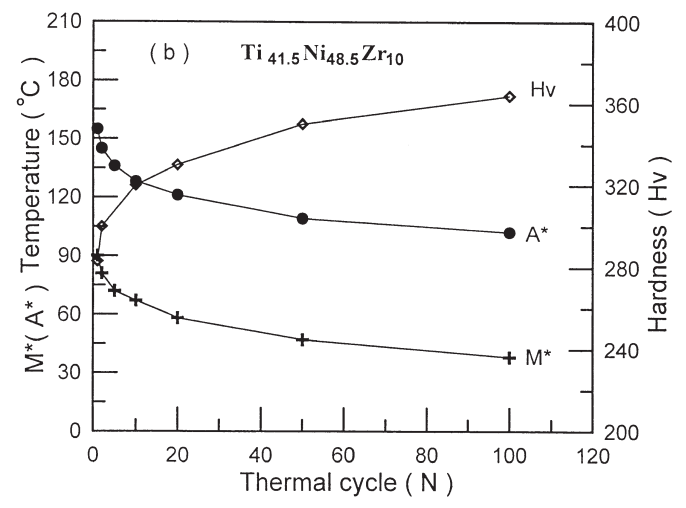

FIG. 7. Peak temperatures $\mathrm{A}^{*}$ and $\mathrm{M}^{*}$ and hardness, $\mathrm{HV}$, versus number of thermal cycles, $N$, for (a) $\mathrm{Ti}_{40.5} \mathrm{Ni}_{49.5} \mathrm{Zr}_{10}$ alloy and (b) $\mathrm{Ti}_{41.5} \mathrm{Ni}_{48.5} \mathrm{Zr}_{10}$ alloy.

ture comes from the thermally cycling induced dislocations [16]. The $\mathrm{A}^{*}$ and $\mathrm{M}^{*}$ values decrease quickly for the first ten cycles, with the decrement of Fig. 7(b), being about $23^{\circ} \mathrm{C}$ at $N=10$, which is larger than that of Fig. $7(\mathrm{a})\left(\cong 19^{\circ} \mathrm{C}\right)$. The increment in hardness of Fig. $7(\mathrm{~b})(\Delta \mathrm{HV}=37)$ also is greater than that of Fig. $7(\mathrm{a})(\Delta \mathrm{HV}=27)$ at the same $N=10$ cycles. This difference indicates that the $\mathrm{Ti}_{41.5} \mathrm{Ni}_{48.5} \mathrm{Zr}_{10}$ alloy can induce more dislocations than the $\mathrm{Ti}_{40.5} \mathrm{Ni}_{49.5} \mathrm{Zr}_{10}$ in the early thermal cycling. This comes from the fact that $\mathrm{Ti}_{41.5} \mathrm{Ni}_{48.5} \mathrm{Zr}_{10}$ alloy has more $(\mathrm{Ti}, \mathrm{Zr})_{2} \mathrm{Ni}$ particles and a higher hardness than in the original. We suggest that the volume change during the martensitic transformation can produce a complex stress field at the interface of $(\mathrm{Ti}, \mathrm{Zr})_{2} \mathrm{Ni}$ particles and the B2/B19' matrix during thermal cycling. This complex stress field can enhance dislocation multiplication, which increases the alloy's hardness and depresses its $\mathrm{M}^{*}$ temperature.

In Fig. 7, after 50 cycles, the $\mathrm{M}^{*}$ and $\mathrm{A}^{*}$ temperatures reach a constant value. This may imply that the quantities of induced dislocations reach a saturated value after $50 \mathrm{cy}-$ cles in these alloys.

\section{COLD-ROLLING EFFECT ON Ti-RICH TiNiZr ALLOYS}

Tables 2 and 3 show the detailed results of DSC and hardness measurements, including $\mathrm{A}^{*}, \Delta H, \mathrm{HV}$, and so forth, for various amounts of cold rolling (0-45\%) in $\mathrm{Ti}_{35.5} \mathrm{Ni}_{49.5} \mathrm{Zr}_{15}$ and $\mathrm{Ti}_{41.5} \mathrm{Ni}_{48.5} \mathrm{Zr}_{10}$ alloys, respectively. The subscripts 1 and 2 of $\mathrm{A}_{1}{ }^{*}, \Delta H_{\mathrm{h} 1}$, and $\mathrm{A}_{2}{ }^{*}$ respectively indicate the specimens subjected to the first and second heating cycle after cold rolling. The data in Table 3 are plotted in Fig. 8 for peak values $\mathrm{M}_{1}{ }^{*}, \mathrm{~A}_{1}{ }^{*}$, and $\mathrm{A}_{2}{ }^{*}$ versus cold rolling for the $\mathrm{Ti}_{41.5} \mathrm{Ni}_{48.5} \mathrm{Zr}_{10}$ alloy. In Fig. 8, $\mathrm{A}_{1}^{*}$ temperatures significantly increase, but $\mathrm{A}_{2}{ }^{*}$ de- 
Table 2 DSC Measurements and Hardness, HV, of $\mathrm{Ti}_{35.5} \mathrm{Ni}_{49.5} \mathrm{Zr}_{15}$ Alloy at Various Thickness Reductions

\begin{tabular}{cccccccc}
\hline $\begin{array}{l}\text { Thicknesss } \\
\text { reduction }(\%)\end{array}$ & $\begin{array}{l}A_{1}{ }^{*} \\
\left({ }^{\circ} \mathrm{C}\right)\end{array}$ & \multicolumn{1}{c}{$\begin{array}{l}\Delta H_{h 1} \\
(\mathrm{~J} / \mathrm{g})\end{array}$} & $\begin{array}{l}M_{1}{ }^{*} \\
\left({ }^{\circ} \mathrm{C}\right)\end{array}$ & $\begin{array}{l}\Delta H_{c} \\
(\mathrm{~J} / g)\end{array}$ & $\begin{array}{l}A_{2}{ }^{*} \\
\left({ }^{\circ} \mathrm{C}\right)\end{array}$ & $\begin{array}{c}\Delta \\
(\mathrm{J} / g)\end{array}$ & $\begin{array}{c}\text { Hardness } \\
(\mathrm{HV})\end{array}$ \\
\hline 0 & 217 & 28.12 & 176 & 24.18 & 207 & 24.79 & 289 \\
5 & 275 & 18.24 & 137 & 14.23 & 203 & 12.35 & 346 \\
10 & 312 & 10.47 & 109 & 9.10 & 168 & 7.41 & 384 \\
15 & 383 & 6.34 & 89 & 5.42 & 145 & 5.59 & 406 \\
25 & 467 & 4.64 & 40 & 4.54 & 116 & 3.85 & 465 \\
\hline
\end{tabular}

creases, with an increasing degree of cold rolling. The $\mathrm{M}^{*}$ temperature also is found to decrease with an increasing amount of cold rolling. This phenomenon is regarded as mechanically induced martensite stabilization, which is the same behavior as that reported for $\mathrm{Ti}_{50} \mathrm{Ni}_{50}$ and $\mathrm{Ti}_{51} \mathrm{Ni}_{49}$ alloys $[8$, 17]. After the occurrence of the reverse

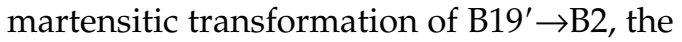
martensite stabilization dies out and $\mathrm{A}_{2}{ }^{*}$ temperatures are dramatically lowered. The possible mechanism for the martensite stabilization illustrated in Fig. 8 is suggested to be the interference of reverse transformation by the cold-deformed structures and deformation-induced defects [17]. The same behavior is also listed in Table 2. From Tables 2 and 3, under the same $15 \%$ cold rolling, the increment of hardness in the $\mathrm{Ti}_{35.5} \mathrm{Ni}_{49.5} \mathrm{Zr}_{15}(\Delta \mathrm{HV}=117)$ is larger than that of the $\mathrm{Ti}_{41.5} \mathrm{Ni}_{48.5} \mathrm{Zr}_{10}$ alloy $(\Delta \mathrm{HV}=$ 102). This feature results from the asannealed hardness of the former alloy being greater than that of the latter alloy.

\section{STRENGTHENING EFFECTS OF COLD ROLLING AND THERMAL CYCLING ON MARTENSITIC TRANSFORMATION TEMPERATURES OF Ti-RICH TiNiZr ALLOYS}

Table 4 gives the peak temperature $\mathrm{M}^{*}$ and hardness $\mathrm{HV}$ of thermal cycled $\mathrm{Ti}_{40.5} \mathrm{Ni}_{49.5} \mathrm{Zr}_{10}$ and $\mathrm{Ti}_{41.5} \mathrm{Ni}_{48.5} \mathrm{Zr}_{10}$ alloys. From Tables 2, 3, and 4 , peak temperature $M^{*}$ is found to decrease with increasing cold rolling percentage and thermal cycling $N$ in these alloys. The decrement of peak temperatures is suggested to be related to the dislocations introduced by cold rolling and thermal cycling. Figure 9 shows the curves of peak temperature $\mathrm{M}^{*}$ versus hardness $\mathrm{HV}$ for the cold-rolled and thermal-cycled $\mathrm{Ti}_{40.5} \mathrm{Ni}_{49.5} \mathrm{Zr}_{10}$, $\mathrm{Ti}_{35.5} \mathrm{Ni}_{49.5} \mathrm{Zr}_{15}$, and $\mathrm{Ti}_{41.5} \mathrm{Ni}_{48.5} \mathrm{Zr}_{10}$ alloys, respectively. The results for cold-rolled and thermal-cycled Ti-rich $\mathrm{Ti}_{51} \mathrm{Ni}_{49}$ alloys also are shown in Fig. 9. It was pointed out that a strengthening mechanism that impedes the transformation shear can lower the transformation temperatures, because the

Table 3 DSC Measurements and Hardness, $\mathrm{HV}$, of $\mathrm{Ti}_{41.5} \mathrm{Ni}_{48.5} \mathrm{Zr}_{10}$ Alloy at Various Thickness Reductions

\begin{tabular}{cccccccc}
\hline $\begin{array}{l}\text { Thicknesss } \\
\text { reduction }(\%)\end{array}$ & $\begin{array}{l}A_{1}{ }^{*} \\
\left({ }^{\circ} \mathrm{C}\right)\end{array}$ & \multicolumn{1}{c}{$\begin{array}{c}\Delta H_{h 1} \\
(\mathrm{~J} / g)\end{array}$} & \multicolumn{1}{c}{$M_{1}{ }^{*}$} & \multicolumn{1}{c}{$\begin{array}{l}\Delta H_{c} \\
(\mathrm{~J} / g)\end{array}$} & $\begin{array}{l}A_{2}{ }^{*} \\
\left({ }^{\circ} \mathrm{C}\right)\end{array}$ & $\begin{array}{c}\Delta H_{h 2} \\
(\mathrm{~J} / g)\end{array}$ & $\begin{array}{c}\text { Hardness } \\
(H V)\end{array}$ \\
\hline 0 & 156 & 26.20 & 90 & 23.03 & 146 & 23.67 & 283 \\
5 & 200 & 17.81 & 60 & 13.23 & 137 & 11.42 & 330 \\
15 & 276 & 10.93 & 30 & 7.80 & 88 & 7.41 & 385 \\
30 & 335 & 3.60 & -17 & 1.64 & 35 & 3.53 & 465 \\
45 & 514 & 6.55 & -46 & 6.42 & 31 & 7.40 & 510 \\
\hline
\end{tabular}




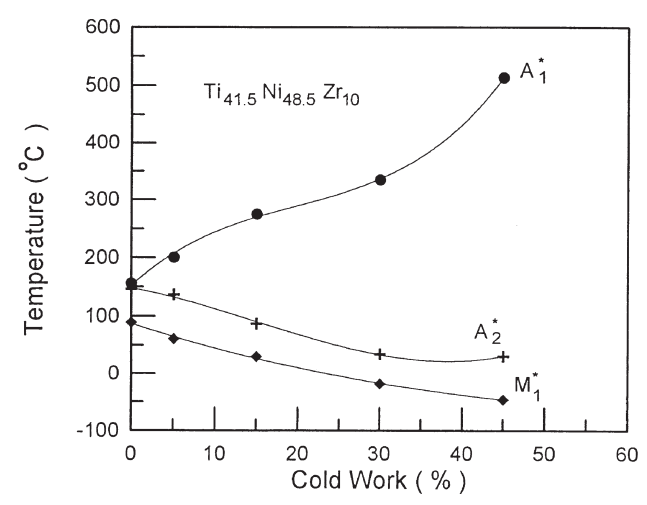

FIG. 8. Transformation peak temperatures $\mathrm{A}_{1}{ }^{*}, \mathrm{~A}_{2}{ }^{*}$, and $\mathrm{M}_{1}{ }^{*}$ versus thickness reduction for the cold-rolled $\mathrm{Ti}_{41.5} \mathrm{Ni}_{48.5} \mathrm{Zr}_{10}$ alloy.

martensitic transformation involves a shear process [18, 19]. This feature can be expressed by Eq. (1):

$$
\mathrm{M}_{\mathrm{s}}=T_{0}-K \Delta \sigma_{\mathrm{y}}
$$

The constant $K$ contains the factors of proportionality between the critical shear stress and the yield stress $\Delta \sigma_{y}$, the equilibrium temperature $T_{0}$ is a function of the chemical composition, and the yield stress $\Delta \sigma_{\mathrm{y}}$ is considered to be proportional to the hardness.

In this study, both cold rolling and thermal cycling do not change the alloy's composition; hence $T_{0}$ is a constant. In addition, both cold rolling and thermal cycling can strengthen the alloys by inducing dislocations and therefore can raise the yield stress $\Delta \sigma_{\mathrm{y}}$. As derived from Eq. (1), this feature should cause the $M^{*}$ and $A^{*}$ temperatures to be lowered by the strengthening effect. This prediction is qualitatively consistent with the results of Fig. 9, in which the slope represents the constant $K$, which is not the same for different strengthening processes. Figure 9 indicates that the processes of cold rolling and thermal cycling can provide different strengthening mechanisms and exhibit different effects on transformation temperatures. For example, the constant $K$ of the $\mathrm{Ti}_{41.5} \mathrm{Ni}_{48.5} \mathrm{Zr}_{10}$ alloy is $0.59 \mathrm{C}^{\circ} / \mathrm{HV}$ for cold rolling, but $0.68 \mathrm{C}^{\circ} / \mathrm{HV}$ for thermal cycling, as shown in Fig. 9. As already mentioned, strengthening processes can introduce dislocations in these alloys. However, dislocations induced by cold rolling come from the plastic deformation of martensite and those induced by thermal cycling come from the thermal stress and transformation shear associated with B2 $\rightarrow$ B19'. Careful examination of Fig. 9(b) reveals that the constant $K$ of the $\mathrm{Ti}_{41.5} \mathrm{Ni}_{48.5} \mathrm{Zr}_{10}$ alloy is larger than that of the $\mathrm{Ti}_{40.5} \mathrm{Ni}_{49.5} \mathrm{Zr}_{10}$ and $\mathrm{Ti}_{51} \mathrm{Ni}_{49}$ alloys for the same strengthening process. We propose that the $K$ value is related to the inherent hardness of annealed TiNi binary or TiNiX ternary alloys. The higher the original hardness, the larger the $K$ value will be. For example, the thermal-cycled $\mathrm{Ti}_{41.5} \mathrm{Ni}_{48.5} \mathrm{Zr}_{10}$ alloy has an annealed hardness of $283 \mathrm{HV}$ and its $K$ value is found to be $0.68 \mathrm{C}^{\circ} / \mathrm{HV}$, which is larger than those of thermal-cycled $\mathrm{Ti}_{40.5} \mathrm{Ni}_{49,5} \mathrm{Zr}_{10}(273 \mathrm{HV}, K=$ $0.65 \mathrm{C}^{\circ} / \mathrm{HV}$ ) and $\mathrm{Ti}_{51} \mathrm{Ni}_{49}(230 \mathrm{HV}, K=0.62$ $\left.\mathrm{C}^{\circ} / \mathrm{HV}\right)$ alloys. This characteristic is also found in cold-rolled alloys, as shown in Fig. 9(a). In other words, the depression of

Table 4 Transformation Peak Temperature, $\mathrm{M}^{*}$, and Hardness, HV, for Different Thermal Cycles in $\mathrm{Ti}_{41.5} \mathrm{Ni}_{48.5} \mathrm{Zr}_{10}$ and $\mathrm{Ti}_{40.5} \mathrm{Ni}_{49.5} \mathrm{Zr}_{10}$ Alloys

\begin{tabular}{cccccc}
\hline & \multicolumn{2}{c}{$\mathrm{Ti}_{40.5} \mathrm{Ni}_{49.5} \mathrm{Z} r_{10}$} & & \multicolumn{2}{c}{$\mathrm{Ti}_{41.5} \mathrm{Ni}_{48.5} \mathrm{Z}$ r $_{10}$} \\
\cline { 2 - 3 } Thermal cycles $(\mathrm{N})$ & $M^{*}\left({ }^{\circ} \mathrm{C}\right)$ & Hardness $(\mathrm{HV})$ & & $M^{*}\left({ }^{\circ} \mathrm{C}\right)$ & Hardness $(\mathrm{HV})$ \\
\hline 1 & 84 & 273 & 90 & 283 \\
2 & 78 & 286 & 81 & 300 \\
10 & 66 & 300 & 67 & 320 \\
20 & 58 & 310 & 60 & 327 \\
50 & 54 & 322 & 47 & 350 \\
100 & 50 & 330 & 36 & 364 \\
\hline
\end{tabular}


$\mathrm{M}_{\mathrm{s}}\left(\mathrm{M}^{*}\right)$ and $\mathrm{A}_{\mathrm{s}}\left(\mathrm{A}^{*}\right)$ temperatures by the strengthening mechanism is stronger for the alloys having a higher annealed hardness. Ti-rich TiNiZr alloys have a higher inherent hardness owing to $\mathrm{Zr}$ atoms in solid solution in the TiNi alloy. This also elucidates why the $K$ values of Ti-rich TiNiZr alloys are higher than that of the $\mathrm{Ti}_{51} \mathrm{Ni}_{49}$ alloy for the same strengthening process, as shown in Fig. 9.

\section{AGING EFFECT ON Ti-RICH TiNiZr ALLOYS}

Figure 10 shows the results of the DSC measurement in the $400^{\circ} \mathrm{C}$ aged $\mathrm{Ti}_{26.5} \mathrm{Ni}_{48.5} \mathrm{Zr}_{25}$ alloy. In Fig. 10, the $\mathrm{A}_{1}^{*}$ temperature increases with increasing aging time. This feature exhibits the phenomenon of martensite stabilization, the same behavior as reported in Cu-based SMAs [20-23]. Two mechanisms were proposed for martensite
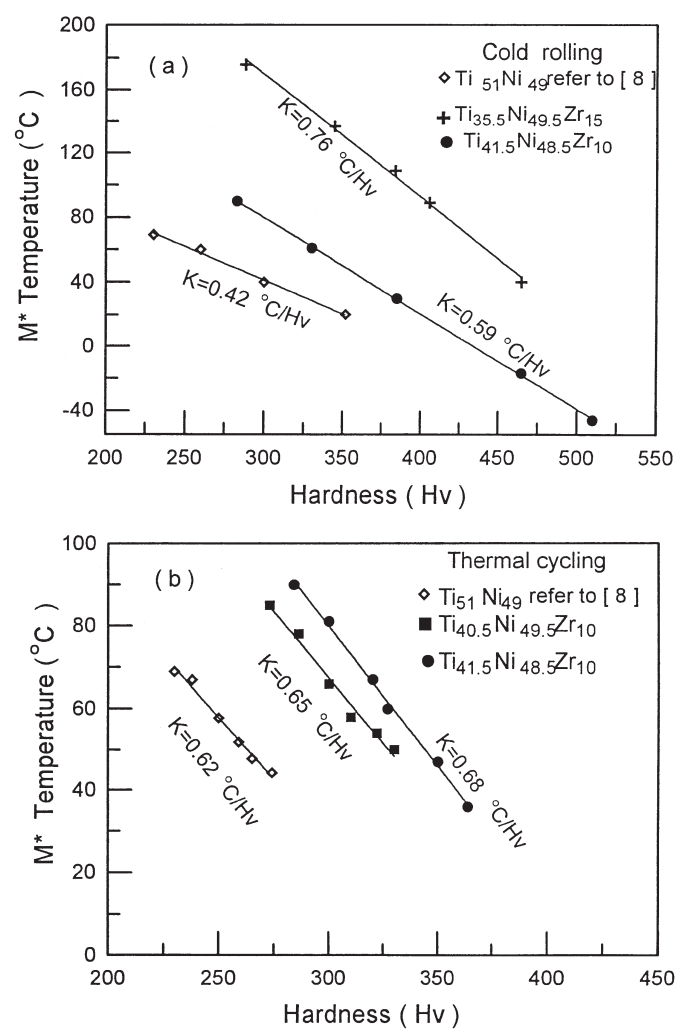

FIG. 9. The temperature $\mathrm{M}^{*}$ versus hardness $\mathrm{HV}$ for (a) cold-rolled and (b) thermal cycled $\mathrm{Ti}_{41.5} \mathrm{Ni}_{48.5} \mathrm{Zr}_{10}$, $\mathrm{Ti}_{40.5} \mathrm{Ni}_{49.5} \mathrm{Zr}_{10}, \mathrm{Ti}_{35.5} \mathrm{Ni}_{49.5} \mathrm{Zr}_{15}$, and $\mathrm{Ti}_{51} \mathrm{Ni}_{49}$ alloys. stabilization in Cu-based SMAs: (1) reordering in martensite, where atomic rearrangement in martensite results in some change in relative stability between parent and martensite [20, 21] and (2) pinning or locking of martensite-parent and martensite-martensite interfaces by aged-induced defects or precipitates [22, 23]. Figure 11(a) shows the a transmission electron micrographic bright-field image of the martensite in a $400^{\circ} \mathrm{C} \times 100 \mathrm{~h}$ aged $\mathrm{Ti}_{26.5} \mathrm{Ni}_{48.5} \mathrm{Zr}_{25}$ alloy. Figure $11(\mathrm{~b}-\mathrm{d})$ shows the SADPs of Fig. $11(\mathrm{a})$, in which the foil is parallel to $[00 \overline{1}]_{\mathrm{M}}$, $[110]_{\mathrm{M}}$, and $[10 \overline{1}]_{\mathrm{M}}$ directions, respectively. No extra reflection spots can be observed in Fig. 11 after the martensite has been stabilized. The martensite phase of TiNi binary SMAs consist of twin-related plates in which self-accommodating groups are formed. If the twins in the martensite plates are assumed to be created by a pole mechanism $[24,25]$, it is reasonable to suggest that a high density of twin dislocations inherently exists in the martensite phase. The same behavior may arise in the $\mathrm{Ti}_{26.5} \mathrm{Ni}_{48.5} \mathrm{Zr}_{25}$ alloy. The interstitial atoms (such as $\mathrm{H}, \mathrm{O}$, etc.) can be put into solid solution in specimens during the arc-melting process, and the excess vacancies can be obtained by quenching the annealed specimen. Therefore, we propose that the immobile interfaces between parent phase B2-martensite or martensite-martensite plates in the martensite stabilized $\mathrm{Ti}_{26.5} \mathrm{Ni}_{48.5} \mathrm{Zr}_{25}$ may be pinned by these point defects.

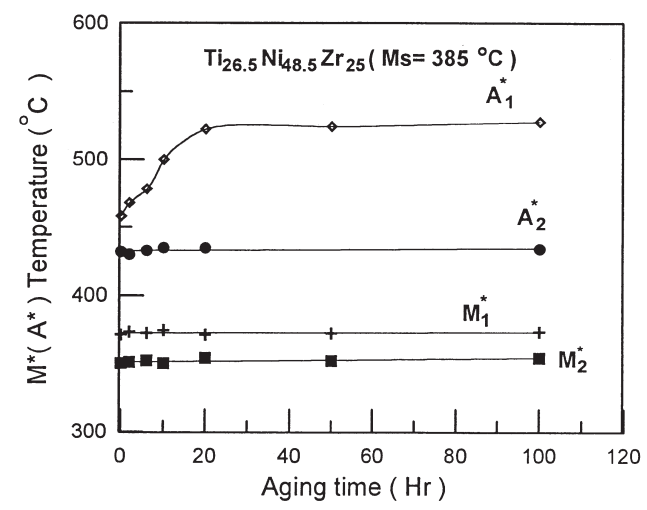

FIG. 10. Peak temperatures $A^{*}$ and $M^{*}$ and hardness $\mathrm{HV}$ versus aging time for $\mathrm{Ti}_{26.5} \mathrm{Ni}_{48.5} \mathrm{Zr}_{25}$ alloy. 

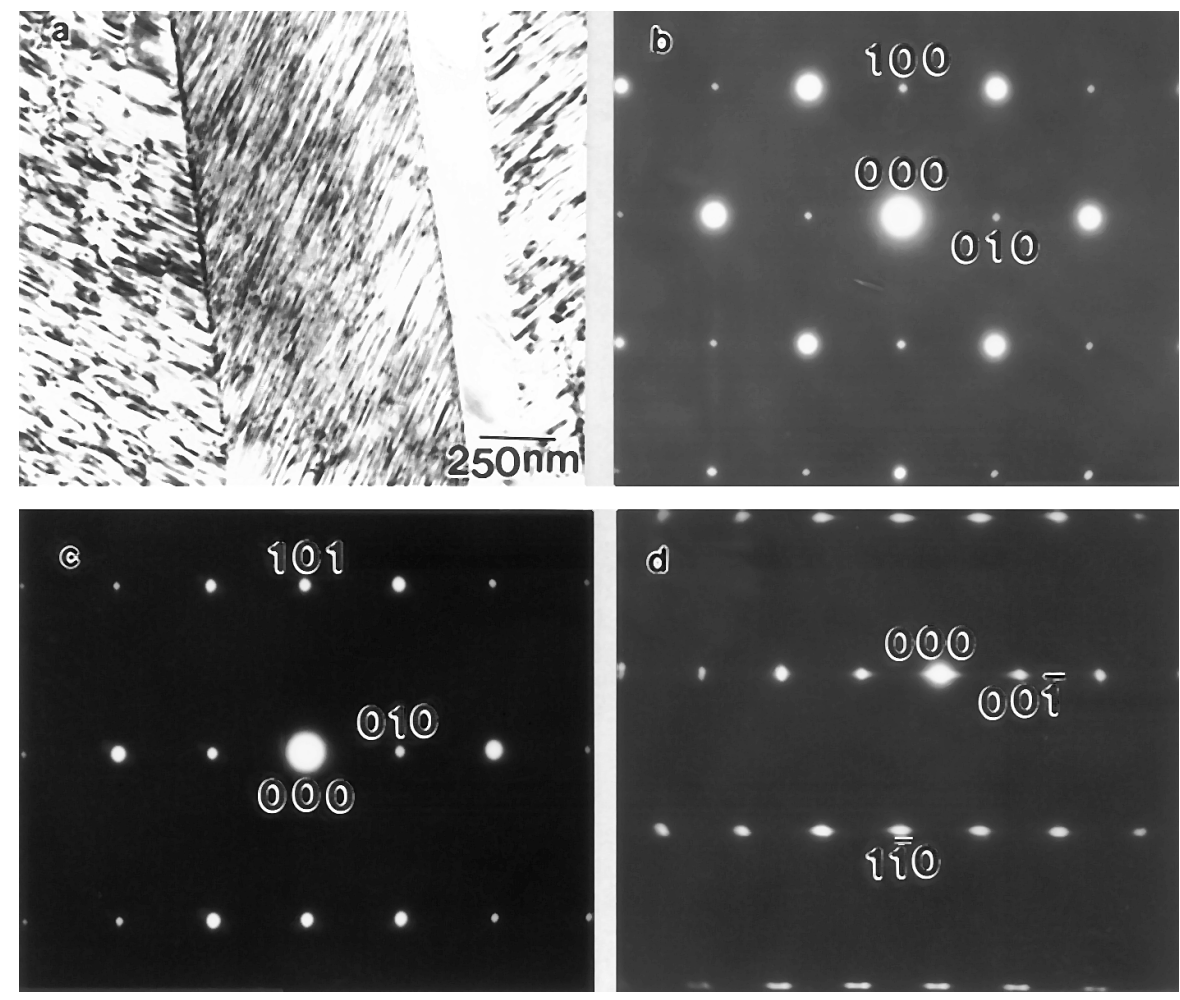

FIG. 11. (a) Bright field image of martensite in $400^{\circ} \mathrm{C} \times 100 \mathrm{~h}$ aged $\mathrm{Ti}_{26.5} \mathrm{Ni}_{48.5} \mathrm{Zr}_{25}$ alloy; (b) SADP of (a), [001] $]_{\mathrm{M}}$ zone; (c) SADP of (a), [110] $]_{M}$ zone; and (d) SADP of (a), [101] $]_{M}$ zone.

\section{CONCLUSION}

1. The annealed $\mathrm{Ti}_{50.5-X} \mathrm{Ni}_{49.5} \mathrm{Zr}_{X}$ and $\mathrm{Ti}_{51.5-}$ ${ }_{X} \mathrm{Ni}_{48.5} \mathrm{Zr}_{X}$ alloys undergo $\mathrm{B} 2 \leftrightarrow \mathrm{B} 19^{\prime}$ martensitic transformation in which the transformation peak temperatures $\mathrm{M}^{*}$ increase from $50^{\circ} \mathrm{C}$ to $450^{\circ} \mathrm{C}$ with increasing $X$ from 0at.\% to 25at.\%. Many second-phase particles are found around the grain boundaries of the matrix. They are $(\mathrm{Ti}, \mathrm{Zr})_{2} \mathrm{Ni}$ particles for alloys with $X \leq$ 10 at. $\%$ and $\lambda_{1}$ phase for alloys with $X \geq$ 15 at.\%. Despite the existence of secondphase particles, the alloys still exhibit good shape recovery, which can reach about $80 \%$.

2. $A^{*}$ and $M^{*}$ temperatures decrease and the hardness increases in the first ten cycles of thermal-cycled $\mathrm{Ti}_{41.5} \mathrm{Ni}_{48.5} \mathrm{Zr}_{10}$ and $\mathrm{Ti}_{40.5} \mathrm{Ni}_{49.5} \mathrm{Zr}_{10}$ alloys. Meanwhile, the decrement of $\mathrm{A}^{*}$ temperatures of the former is larger than that of the latter at the same cycle, owing to the former's having the harder matrix and the greater number of $(\mathrm{Ti}, \mathrm{Zr})_{2} \mathrm{Ni}$ particles.

3. Martensite stabilization of $\mathrm{Ti}_{41.5} \mathrm{Ni}_{48.5} \mathrm{Zr}_{10}$ and $\mathrm{Ti}_{35.5} \mathrm{Ni}_{49.5} \mathrm{Zr}_{15}$ alloys can be induced by cold rolling at room temperature. The hardness increment of the former is less than that of the latter under the same degree of cold rolling, owing to the latter's being harder than the former in the annealed condition.

4. The strengthening effects of cold rolling and thermal cycling on $\mathrm{M}_{\mathrm{S}}\left(\mathrm{M}^{*}\right)$ temperatures of $\mathrm{Ti}_{41.5} \mathrm{Ni}_{48.5} \mathrm{Zr}_{10}, \mathrm{Ti}_{40.5} \mathrm{Ni}_{49.5} \mathrm{Zr}_{10}$, and $\mathrm{Ti}_{35.5} \mathrm{Ni}_{49.5} \mathrm{Zr}_{15}$ alloys are found to be in accord with the equation $\mathrm{M}_{\mathrm{s}}=T_{0}$ $K \Delta \sigma_{\mathrm{y}}$. Strengthening processes of cold rolling and thermal cycling have different $K$ values. Experimental results show that $K$ values are associated with the inherent hardness of the annealed $\mathrm{TiNi}$ and TiNiX alloys. The Ti-rich TiNiZr alloys have $\mathrm{Zr}$ atoms in solid solution and thus have a higher annealed hardness 
than that of the $\mathrm{Ti}_{51} \mathrm{Ni}_{49}$ alloy. This causes Ti-rich TiNiZr alloys to have higher $K$ values than that of the $\mathrm{Ti}_{51} \mathrm{Ni}_{49}$ alloy under the same strengthening process.

5. Martensite stabilization of the $\mathrm{Ti}_{26.5} \mathrm{Ni}_{48.5} \mathrm{Zr}_{25}$ alloy occurs at the $400^{\circ} \mathrm{C}$ aging treatment because the interfaces of $\mathrm{B} 2$-martensite or martensite-martensite plates may be pinned by point defects.

The authors are grateful to Dr. T. S. Chou, Steel and Aluminum $R \mathcal{E} D$ Department, China Steel Corporation, for his great assistance with the internal friction measurement. The financial support of this study by the National Science Council (NSC), Republic of China, under Grant No. NSC 85-2216-E002-022, is also sincerely appreciated.

\section{References}

1. H. C. Yi and J. J. Moore: Combustion Synthesis of Ti-Pd and Ti-Ni-Pd High Transition Temperature Shape Memory Alloys. Proc. Int. Conf. on Martensitic Transformation, Sydney, Australia (July 3-7, 1989).

2. P. G. Lindqist and C. M. Wayman: Shape Memory and Transformation Behavior of Martensitic TiPd-Ni and Ti-Pt-Ni Alloys. Engineering aspects of shape memory alloys. T. W. Duering, K. N. Melton, D. Stockel, and C. M. Wayman, eds., Butterworth Heinemann, London, p. 58 (1990).

3. Y. C. Lo, S. K. Wu, and C. M. Wayman: Transformation heat as a function of ternary Pd additions in $\mathrm{Ti}_{50} \mathrm{Ni}_{50-X} \mathrm{Pd}_{X}$ alloys with $x=20-50$ at.\%. Scr. Metall. 24:1571-1576 (1990).

4. S. K. Wu and C. M. Wayman: Martensitic transformations and the shape memory effect in $\mathrm{Ti}_{50} \mathrm{Ni}_{10} \mathrm{Au}_{40}$ and $\mathrm{Ti}_{50} \mathrm{Au}_{50}$ alloys. Metallography 20:359-376 (1987).

5. L. Meisner and V. P. Sivokha: Deformation of crystal lattice in the process of martensitic transformation in alloys of $\mathrm{Ni}_{50} \mathrm{Ti}_{50-x} \mathrm{Zr}_{x}$. J. Phys. IV C8: 765-769 (1995).

6. S. F. Hsieh and S. K. Wu: Room-temperature phase observed in $\mathrm{Ti}_{53-X} \mathrm{Ni}_{47} \mathrm{Zr}_{X}$ high-temperature shape memory alloys. J. Alloys Compounds 266: 276-282 (1998).

7. J. H. Mulder, J. H. Mass, and J. Beyer: Martensitic Transformations and Shape Memory Effects in Ti-Ni$\mathrm{Zr}$ Alloys. Proc. Int. Conf. on Martensitic Transformations, Monterey, CA (July 20-24, 1992).

8. H. C. Lin, S. K. Wu, and J. C. Lin: The martensitic transformation in Ti-rich TiNi shape memory alloys. Mater. Chem. Phys. 37:184-190 (1994).

9. S. H. Chen: A study on ternary Ti-rich $\mathrm{Ti}_{51.5-\mathrm{X}^{-}}$
$\mathrm{Ni}_{48.5} \mathrm{Zr}_{X}$ shape memory alloys. Master's Thesis, Institute of Materials Science and Engineering, National Taiwan University, Taipei, Taiwan (1994).

10. H. C. Lin and S. K. Wu: Strengthening effect of shape recovery characteristic of the equiatomic TiNi alloys. Scr. Metall. 26:59-61 (1992).

11. K. H. Eckelmeyer: The effect of alloying on the shape memory phenomenon in nitinol. Scr. Metall. 10:667-672 (1976).

12. X. D. Han, W. H. Zou, R. Wang, Z. Zhang, D. Z. Yang, and $\mathrm{K}$. H. Wu: The martensite structure and aging precipitates of a TiNiHf high temperature shape memory alloy. J. Phys. IV C8:753-758 (1995).

13. S. K. Wu, H. C. Lin, and T. S. Chou: A study on electrial resistivity, internal friction and shear modulus on an aged $\mathrm{Ti}_{49} \mathrm{Ni}_{51}$ alloy. Acta Metall. 38: 95-102 (1990).

14. H. C. Lin: A study on binary TiNi shape memory alloys. Ph.D. Thesis, Institute of Materials Science and Engineering, National Taiwan University, Taipei, Taiwan (1992).

15. J. S. Zhu, R. Schaller, and W. Benoit: Relaxation peak near $200 \mathrm{~K}$ in NiTi alloy. Phys. Lett. A 141: 177-180 (1989).

16. S. Miyazaki, Y. Igo, and K. Otsuka: Effect of thermal cycling on the transformation temperatures of TiNi alloys. Acta Metall. 34:2045-2051 (1986).

17. H. C. Lin, S. K. Wu, T. S. Chou, and H. P. Kao: The effects of cold rolling on the martensitic transformation of an equiatomic TiNi alloy. Acta Metall. 39:2069-2080 (1991).

18. M. Cohen, E. S. Machlin, and V. G. Paranjpe: Thermodynamics in Physical Metallurgy. American Society for Metals, Metals Park, OH, p. 242 (1950).

19. E. Hornbogen: The effect of variables on martensitic transformation temperatures. Acta Metall. 33: 595-601 (1991).

20. G. Scarsbrook and W. M. Stobbs: The martensitic transformation behavior and stabilization of rapidly quenched $\mathrm{Cu}-\mathrm{Zn}-\mathrm{Al}$ ribbons. Acta Metall. 35: 47-56 (1987)

21. A. A. Arab, M. Chandrasekaran, and M. Ahlers: Martensite aging and its stabilization in $\mathrm{Cu}-\mathrm{Zn}-\mathrm{Al}$ shape memory alloys. Scr. Metall. 18:709-714 (1984).

22. M. Ahlers: The Stabilization of Martensite in $\mathrm{Cu}-\mathrm{Zn}$ Al. Proc. Int. Conf. on Martensitc Transformation, Nara, Japan (August 26-30, 1986)

23. M. H. Wu and C. M. Wayman: Isothermal aging of martensite in a $\mathrm{Cu}-\mathrm{Zn}-\mathrm{Al}$ shape memory alloy. Mater. Sci. Forum 56-58:553-558 (1990).

24. R. E. Reed-Hill: Physical Metallurgy Principles. 3rd ed., PWS-Kent Pub., Boston, p. 552 (1992).

25. J. W. Christian: The Theory of Transformations in Metals and Alloys. Pergamon Press, Oxford, England, p. 792 (1965).

Received March 1998; accepted April 1998. 